\title{
Correction to: Evaluating the ecotoxicity of nitrification inhibitors using terrestrial and aquatic test organisms
}

\author{
Julia Elli Kösler, Olga C. Calvo ${ }^{*}$, Jürgen Franzaring and Andreas Fangmeier(D)
}

\section{Correction to: Environ Sci Eur (2019) 31:91 https://doi.org/10.1186/s12302-019-0272-3}

After publication of the original article [1], the authors noticed an error concerning the ingredients of the used product Vizura ${ }^{\circledR}$. The product does not contain a triazole, but a pyrazole as part of DMPP (3,4-dimethylpyrazolephosphate).

Following text passages are affected:

Page 2 (Background): "Piadin contains a mixture of 1H-1,2,4-triazole and 3-MP, whereas Vizura contains a mixture of DMPP and 1H-1,2,4-triazole as active ingredients."

Should read:

Vizura contains a mixture of $1 \mathrm{H}$-pyrazole and 3,4-dimethyl-phosphate (1:1) (DMPP) as active ingredients.

Page 2 (Materials and methods): "Vizura contains 15\% of the two active compounds DMPP and $1 \mathrm{H}-1,2,4$-triazole (1:1) and 50\% phosphoric acid."

Should read:

Vizura contains $15 \%$ of the active compound DMPP (3,4-dimethylpyrazolephosphate) and $<50 \%$ phosphoric acid.

The original article can be found online at https://doi.org/10.1186/s1230 2-019-0272-3.

*Correspondence: O.Calvo@uni-hohenheim.de

Institute of Landscape and Plant Ecology, University of Hohenheim,

August-von-Hartmann Str. 3, 70599 Stuttgart, Germany
Page 9 (Discussion part Vizura): "Comparable data for Vizura and Lemna are missing, but BASF gives some information about the effects of the active ingredients DMPP and 1H-1,2,4-triazole (1:1) on the cyanobacterium..."

Should read:

Comparable data for Vizura and Lemna are missing, but BASF gives some information about the effects of the active ingredient DMPP on the cyanobacterium...

Page 9 (Discussion part Vizura): "At this point it should be stated that also Vizura contains aromatic compounds (1H-triazole) which could be the reason for phytotoxic effects."

Should read:

At this point it should be stated that also Vizura contains aromatic compounds ( $1 \mathrm{H}$-pyrazole) which could be the reason for phytotoxic effects.

Published online: 04 April 2020

\section{Reference}

1. Kösler JE, Calvo OC, Franzaring J, Fangmeier A (2019) Evaluating the ecotoxicity of nitrification inhibitors using terrestrial and aquatic test organisms. Environ Sci Eur 31:91

\section{Publisher's Note}

Springer Nature remains neutral with regard to jurisdictional claims in published maps and institutional affiliations.

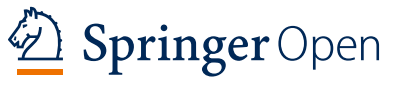

(0) The Author(s) 2020. This article is licensed under a Creative Commons Attribution 4.0 International License, which permits use, sharing, adaptation, distribution and reproduction in any medium or format, as long as you give appropriate credit to the original author(s) and the source, provide a link to the Creative Commons licence, and indicate if changes were made. The images or other third party material in this article are included in the article's Creative Commons licence, unless indicated otherwise in a credit line to the material. If material is not included in the article's Creative Commons licence and your intended use is not permitted by statutory regulation or exceeds the permitted use, you will need to obtain permission directly from the copyright holder. To view a copy of this licence, visit http://creativecommons.org/licenses/by/4.0/. 